\title{
Digital Media and Cultural Globalisation: The Fate of African Value System
}

\author{
Balarabe Maikaba, Aondover Eric Msughter \\ Department of Mass Communication, Bayero University Kano, Kano, Nigeria \\ Email address: \\ balamaikaba@gmail.com (B. Maikaba),Aondover7@gmail.com (A. E. Msughter)
}

\section{To cite this article:}

Balarabe Maikaba, Aondover Eric Msughter. Digital Media and Cultural Globalisation: The Fate of African Value System. Humanities and Social Sciences. Special Issue: Digital Media and Cultural Globalisation: The Fate of African Value System.

Vol. 7, No. 6, 2019, pp. 214-220. doi: 10.11648/j.hss.20190706.15

Received: June 11, 2019; Accepted: October 22, 2019; Published: December 31, 2019

\begin{abstract}
The study set to examine digital media and globalisation in order to determine the fate of African value system. Digital media can be used to change social practices as well as societal-level transformation. If countries all over the world use the same technology, then they will gradually converge as the technologies shape them and they slowly lose their distinctiveness. Globalization on the other hand is a continuation and expansion of western imperialism. It is a fresh phase of recolonization of African societies which attempts to continue the promotion of western linguistic heritage and literacy canons at the expense of African indigenous languages and literature. Globalization tends to diminish the value of cultural practices of Africa. The culture of the developed economy has obviously taken over the local culture. African societies are directly or indirectly forced to accept uniform moral principles of what is right and wrong within global cultures. In order to achieve the objective of the study, qualitative research method is adopted whereby relevant literature, documents and records are consulted and analysed in order to underscore digital media or globalisation and the fate of African value system. To locate the study within the context of theoretical framework, Media Imperialism Theory is employed. The findings of the study revealed that digital media and globalisation are exerting significant influence on the production and consumption of media products and acculturation. The study concludes that the challenges digital media and globalization pose to Africa are nothing more than challenges for Africans to adopt development policies that are rooted in their cultural value systems. The study recommends that Africans should imbibe the positive tenets that come with technology and neglect the negative aspects. Again, there is need for researchers to develop interest in this area so as to expand the body of literature and knowledge.
\end{abstract}

Keywords: African Culture, Digital Media, Global Culture, Globalisation, Value System and Western Imperialism

\section{Introduction}

Scholars like Mofoluwawo [1] and Oladiti [2] establish in the literature, that every human society, developed or underdeveloped has its approved standard way of human relations. Such standards are based on a positive behaviour guided by traditions, norms, values and rules that reflect in the manner of speaking, decent way of dressing, honesty, love, cooperation, hardworking, patriotism and a lot more. They maintained that, it is a fact that smooth running and healthy relationship cum development of any given society depend on those esteemed moral values and cultural traits. This could be the reason why Boli and George [3] articulate that the relative availability and affordability of long distance travel brought a greater portion of the population in contact with other cultures. An important feature of digital media and globalization is the interchange of ideas symbolized by the internet. The concern involves the clash of cultures and the spread of materialistic values.

The development of the Internet allows any person to have access and wonder into Hollywood Library and no one is there to stop, control or direct you. This has great influence on how people think, act or behave; the values these entertainment industries reflect to promote materialism, violence and immorality. African traditional society had very rich cultural heritage that emphasizes sound moral values among her people. This was stated by Fafunwa [4] in the aims and objectives of indigenous educational system in Nigeria. The objectives emphasized the concept of Omoluabi, meaning a responsible, discipline, cooperative and 
hardworking individual that would contribute their own positive quota towards the development of self and the community. Indigenous education is also essential for the transmission of society's norms and values. Obidi [5] observes that children's education began in the nuclear and extended family circles. During family meeting and visits to relatives, children learned about their origins, ancestors, heritage and the origin of annual festivals.

Taking digital media and globalisation side by side, Marcus [6] establishes that, digital media can directly change and transform social practices or whether such technology simply facilitate prior-existing desire and allows people to do what they want to do but do it better. Some argue that the widespread use of a particular technology such as digital technology will drive a society in a particular direction. It is argued that digital technology can be used to encourage development and bring about societal-level transformation. However, if countries all over the world use the same technology, then they will gradually converge as the technologies shape them and they slowly lose their distinctiveness. Croteau and Hoynes [7] are of the view that globalization is not just about the technological innovations used to communicate over long distances. In addition, and perhaps more importantly, it refers to the exchange and intermingling of cultures from different parts of the globe. The globalization of media especially, refers to the content of the cultural products available globally.

\subsection{Justification, Objective and Methodology}

In the assessment of the impact of digital media and globalization on individuals, nations and the global world, scholars like Kwame [8] and Ogoko [9] have expressed divergent and dissenting views. While they all agree that globalization has a political, economic, cultural and even religious impact on individuals, nations and the world at large, they however, disagree on the nature and extent of this impact. While some argue that it is all positive, some believe that it has nothing but negative impacts. Yet others see it as being both positive and negative. Apparently, Ekwuru [10] is of the view that, no man is an island to himself. Likewise, no nation is an island to herself. Therefore, in the process of international interactions, there is an interaction of cultures and thus, a borrowing and diffusion of cultures amongst nations. This is in itself not unusual; but unusual and unfortunate is the domination of one culture over the other. To him, this is an evil, an evil of forced acculturation.

Therefore, there is a growing consensus that digital media and globalisation are exerting significant influence on the production and consumption of media products and acculturation, Abubakar, [11]. It is against the foregoing that this study set to interrogates the African core values of modesty, honesty, decency, respect, truth, among others in the era of digital media and globalisation dominated century. The study is exploratory, as it utilises the qualitative research method whereby relevant literature, documents and records were conceptualised and analysed in order to underscore digital media or globalisation and the fate of African value system.

\subsection{Definitions of Key Concepts}

Digital Media: It is an engagement of an up-to-date media platforms that have adequate facilities in terms of interaction and capable of influencing acculturation.

Globalisation: It is the creation of the whole world into a single entity with priority to same language, same culture, same mode of dressing and same political, social and economic apparatus.

Value System: Is the integration of societal norms and morals that are unique and apparent to a particular culture.

\section{Research Premise}

The main concern of this study is to examine digital media/globalisation and the fate of African value system. Thus, the thrust of this study is anchored on the Media Imperialism Theory. The media imperialism paradigm evolved in the 1960s and 1970s out of Latin American dependency theory, partly as "a critical reflection of the development approach which regards mass media as accelerating the modernisation of developing countries" Lee cited in Free Library, [12]. This all encompassing "definitions of cultural imperialism and the assumption of self evident consequences have been critiqued as functional and less receptive to empirical analysis". While sticking to the basic assumption of cultural imperialism, Boyd-Barrett, (cited in the Free Library [12] adopts the term media imperialism and defines it as the process whereby the ownership structure, distribution or content of the media in any one country are singly or together subject to substantial external pressures from media interest of any other country or countries without proportionate reciprocation of influence by the country so affected, Asemah, [13].

According to Asemah, Nwammuo and Ukwam-Uwaoma [14] "the issue of cultural imperialism emerged largely from communication literature involving development and political economy". These orientations ultimately constructed formulations concerning cultural heritage and behavior based on an analysis of government, corporate policy and practice. The term "cultural imperialism" has been used to describe and explain the way in which large multinational corporations, including the media of developed countries dominated developing countries.

Media imperialism is a theory based on an over concentration of mass media from large nations as a significant variable in negatively affecting smaller nations, in which the national identity of smaller nations is lessened or lost due to media homogeneity inherent in mass media from the lager countries. The theory was formerly propounded by Schiller in 1976. The major assumption of the theory is that information flows from the rich information areas of the west to the developing countries (third world countries).

The theory further holds that information flow is changing the cultural identities of the developing nations. The import of the foregoing is that the western nations dominate the media around the world which in turn, have a powerful effect 
on the third world cultures by imposing on them, western values and thereby, destroying their own native cultures. Cultural imperialism by definition is the process by which the importation of news and entertainment from the developed, industrial world; for example, United States culture overwhelms or dominates the culture of developing countries. Anaeto, Onabajo and Osifeso [15] summarise the cultural imperialism theory thus:

The Western countries are technologically developed in television and motion programmes. The developing countries that are not technologically developed depend on the programmes from the developed countries. This means that the programmes from the developed countries which portray their cultures will be imbibed by the developing nations ( $\mathrm{p}$. 105).

The media messages from the developed nations come to developing nations with their cultural values. This western culture now dominates the local cultures because they are consuming their mass media messages. This is cultural imperialism. The above assertion shows that the developing countries are at the receiving end when it comes to international news flow (international communication). This explains why the western culture is gradually dominating African value system.

\section{Perspective on Digital Media and Globalisation}

One of the defining characteristics of the kinds of media under study is that they are digital, Lister, Dovey, Giddings Grant and Kelly, [16]. This means that all the information or data in these media is encoded in numbers. The most common numerical system used is the binary code of 0 and 1: all information is therefore converted in a series of $0 \mathrm{~s}$ and 1s, Siapera, [17]. Information such as a name can be represented by any arbitrary combination of numbers. From this point of view the interpretation of the digital code is independent of its representation. On the other hand, analogue media encoded and store information in corresponding physical objects. Thus, sound, text and images elicit analogous responses in vinyl, paper or film. This is a relationship of more or less direct correspondence of encoded information and physical objects, in which information is interpreted in an equally direct manner. For example, words are encoded in a book by pressing metallic letters on paper and once printed they cannot change. Recorded music is encoded by carving grooves in vinyl.

Lister et al [16] refers to four main outcomes of the turn towards digital media. First, media texts become de-linked from particular media. One can now read books on the internet or on Kindle, which television or films online or on mobiles phones and upload photographs on blog or hang them on digital frames. This attribute leads to the muchtalked about media convergence, Jenkins, [18]. Second, information can be compressed and fitted into very small spaces or even accessed remotely: portable devices, USB sticks and external hard drives can store astonishing amounts of information, while the 'cloud' (i.e. servers to which users can connect remotely though the internet) can offer almost unlimited storage and can be accessed anytime and anywhere. A third outcome of digitalisation is that access to data can be very fast and also does not have to be linear.

Imagine that one has stored all kind of books in a flash drive or on one's computers' hard disk or in the cloud. One can access to any of this book in this collection in a matter of seconds and also information within this book without having to flip through all the pages one by one. Finally, a more ambivalent outcome of digitalisation is that data can be manipulated in ways unimaginable in the analogue media age. In the Stalinist Soviet Union, disgraced party members would disappear from official photographs and records through painstaking by photography experts, King, [19]. Careful examination could easily reveal the falsification of the photographs. Digital photographs have reversed the situation: retouching is available to all of us at a click of few buttons. While this may be a useful tool removing 'red eyes' from pictures, it can clearly have more sinister uses.

Therefore, there is no doubt that the process of digitalizing the media has had profound effects. In the European Union, the 2012 digital switchover has put a formal end to analogue media. The process of digitalisation has turned all media into digital media. But how does this tem fare when it comes to understanding the media? With its emphasis on the mode of encoding and converting data and information, the term 'digital media' seems to focus primarily on the technological element of the media. To talk of digital media therefore appears to prioritise aspects that relate to the technology that made them possible. While the technological element is without doubt influence the way people interact on social media. This could be the reason why Siapera posits that the technology is the defining dimension of the media overlooks the ways in which users shape them or the broader sociocultural and economic environment which produced them in the first place.

According to Ogoko (9) the political idea of globalization is the aggregation of compliant nations of the world into a community wherein their territorial boundaries dissolve into ideological insignificance while retaining their political sovereignty as independent nations. In principle the countries remain sovereign and autonomous but in practice the restrictions, the obstacles, cross border problems etc. that tend to hinder easy integration and cooperation amongst nations that are cleared; cross border flow of capitals, goods and services and other social activities that encourage full integration and cooperation are encouraged. There is total trade liberation but only as a scheme to predetermine the fate of other nations.

In his submission of the term globalization, Nsibami [20] incorporates five concepts definitive of globalization. According to him, globalization is a process of advancement and increase in interaction among the world's countries and people facilitated by progressive technological changes in locomotion, communication, political and military power, 
knowledge and skills, as well as interfacing of cultural values, systems and practices. He adds that globalization is not a value free, innocent, self-determining process. It is an international, socio-politico-economic and cultural permeation process facilitated by policies of government, private corporations, international agencies and civil society organizations. Corroborating this Fischer articulates globalization as a 'process of linking regions and/or nations of the world which is facilitated by information flow (communication) inducing changes in the pre-existing sociocultural, political, economic etc, structures and systems of nations and peoples'.

Aborishade [21] maintains that globalization is Western imperialism, particularly American imperialism that seeks to impose its hegemony on other subjugated and exploited nations' threat of economic, political or military coercion. To him, globalization does not only deepen inequality between the core and the periphery nations, it also seeks to wage unprecedented attacks on the right and welfare of the poor nations. Scholars like Ugbam, Chukwu and Ogbo [22] classify globalization in the same category with colonialism, imperialism and modernization.

\subsection{Perspectives on Cultural Globalization}

Globalization is a critical tool for cultural homogeneity, an end to cultural diversity in the world. The cultural and linguistic differences accompanying ethnic division in Africa have been weakened by the forces of globalization. Cultural globalization refers to diffusion processes of cultural products to other societies. African traditional cultural values are being replaced by the globalization aimed at the diffusion of culture, commerce and communication of countries of the world in order to bring about homogenization. Globalization aims at cultural homogenization and moreover, the culture that will emerge at the end of the day will be predominantly American and apparently it will become Americanization. The appropriation of life-styles, ideas, cultural symbols and customs from their original societal context, together with their adaptation, reinterpretation and integration into existing practices are subject matter of cultural globalization.

Iyayi [23] posits that cultural globalization has been used rather loosely to stand for a variety of things; the shrinking of the world into a global village, the awesome changes brought about or mandated by the revolution in information technology, the collapse of boundaries between different worlds, expanding connectivity of all forms of interaction. Another aspect of cultural globalization is the cheap and fast information and communication technology (ICT) which is playing a key role in globalization and integration. It has facilitated the heralding of a "third wave" comparable to the first wave, the agricultural revolution and the second wave, the Industrial Revolution. The world is shifting from a manufacturing-based industrial economy to a service dominated and network-based knowledge economy, Mohanty, [24].

However, in as much as internet provides enormous convenience as well as propels the nation's economy, the internet which is open and free has also brought with it negative challenges that cannot be overlooked. The internet is known to corrupt the minds of people. It also influences and changes people's moral perspectives and ethical values. Youth also have free access to films like horror films, pornography and sex films, nude dressing, slangs and images of all sorts at almost every parts of the world. Cultural globalization has direct relation with moral values of individual societies based on their belief system, orientation and philosophy of life which is different from one country to another. The cultural distinct societies of the world are being overrun by globally available goods, media, ideas and institutions which eventually lead to cultural fragmentation and inter-cultural conflict leading to high-rate of moral decadence. The over bearing influence from other cultures according to Kelani [25] has led to the death of language and culture in Nigeria.

\subsection{Understanding Morality and Moral Values}

Morality in its descriptive usage means a code of conduct held to be authoritative in matters of right and wrong. In its second normative and universal sense, morality refers to an ideal code of conduct, one which would be imbibed in preference to alternatives by all rational people underspecified conditions. To deny 'morality' in this sense is a position known as moral skepticism, Falade, [26]. In its third usage, morality is synonymous with ethics, the systematic, philosophical study of the moral domain. Morality is used to denote a generally accepted code of conduct in a society or within a subgroup of society that comes to be regarded as essential to its survival and welfares. These accepted norms or codes of conducts in any society often appeal to the moral nature of man "for the human nature is a moral nature and the moral sphere is exclusively the human spheres", Omoregbe, [27]. It should be stressed that the systematic study of morality is a branch of philosophy axiology i.e. ethics/values based on objectives as the health of the society.

Moral values are deep seated beliefs that influence people's actions and rules by which decisions are made within societies. Moral values are philosophical considerations which help an individual personally to judge how reasonable, truthful and appropriate his actions are in relations with others. Morality and moral values are very important because the question of right and wrong, good or bad cannot be undermined in any human society. Some of the common moral values required of a moral upright individual are respect for the sanctity of human life, intrinsic honesty, respect for elders, hard work and industry, kindness, selflessness, commitment, loyal, productive, discipline, pathetic, integrity, avoidance of premarital sex and a host of others.

In the same vein, an immoral man is sick and an immoral society is equally a sick society. Immoral society could means a society permeated with dishonesty, selfishness corruption, fraud, disloyal, lack of respect for elders and constituted authorities, lack of discipline, commitment and a host of other social vices. 


\section{Discussion on Digital Media, Globalisation and the Fate of African Value System}

Acholonu [28] examines media and cultural imperialism in Africa. The rationale for the study was to examine ways the media can be used to advance African culture instead of promoting foreign programmes that debase African culture. Her findings showed that African media promote more of the western culture to the neglect of the African culture. Based on her findings, she recommended that African news agencies and mass media should adopt communication policies to favour cooperation among all African mass media and channel development according to African values, needs, aspiration and ideology.

Chigbo [29] commenting on cultural imperialism, notes that media are a large business corporations that are employed to guarantee the cultural dominance and economic dependency and maintain the difficulty in free exchange, equality and balance in international communications and free flow of information. The industrialised North retains absolute monopoly of the invention, ownership and control of the communication media and information technology.

This perhaps explains why Izuogu [30] says that the world is gradually reducing into one entity in which everything "West" is held as a model against all things from other parts. Cultural imperialism is used to describe the western culture domination of international mass communication because the western culture imposes its values, beliefs, assumptions, language, etc, upon a dependent third world culture through the process of global mass communication.

Akintayo [31] examines the influence of foreign programmes on the socio-cultural behaviour of Olabisi Onabanjo University Student (OOU). The findings show that foreign television programmes have influenced students in tertiary institutions in Nigeria in which they have sold out their own cultural values to the foreign world as they are being brainwashed of everything they have learnt over the years, making them see it as an old way of life. She recommends that media proprietors should ensure that broadcast contents embrace more of local and in-house productions that promote cultural values of Nigerians.

In Poe's [32] admirably lucid accounts, changes in communication technology are a cause of changes in social practice. This happens by means of the interaction between properties of the technology of communication properties of the social formation. The properties of the social formation are of two broad kinds, namely: human nature (i.e. those things people are genetically wired to do as humans) and material-historical conditions (i.e. the nexus of political, economic, social and cultural circumstances in which people exist).

From an empirical point of view, there have undoubtedly been clearly observable changes in Nigerian cultures over the decades. The negative aspects of these changes have been aptly captured by various commentators on the issue.
Ogunjimi and $\mathrm{Na}$ 'Allah [33] state that the peculiar Nigerian cultural values, like languages, are being eroded by the pop culture brought about by globalization. Greeting norms, cuisine, appearance and dress, custom, occupations, religion and cultural components are giving way to acculturation "the suppression and subjugation of African culture," a tragic phenomenon that is fast destroying the original cultural complexion of not only the budding generation but even the adults.

The negative effects of globalization seem to be more conspicuous and alarming among the youths. Oni [34] observes that Nigerian youths are rapidly losing touch with cultural values and that this could be seen in the alien culture which they portray; their bizarre dressing, dancing and language and so on which invariably affect other aspects of social life. Unfortunately, this is not peculiar to Nigerian youths. Nicolaides [35] made a similar observation about South African youths. He states as follows:

The younger generation of teenagers in south Africa have for the most part abandoned their African culture and language and often religion and try to be hip by imitating their mainly American rap artist role models who for most part display an acute lack of values and act immorally on television shows and who promote promiscuous behaviour especially in the lyrics of the music they write (p. 123).

Youths are supposed to promote African culture and at the same time help to transmit it from one generation to the other. Therefore, it is deplorable when they fail to play this role. As Bello and Adesemoye in Nicolaides [35] capture it:

Teenagers and youths generally are vital segments of the society who could be instrumental in promoting African cultures. But unfortunately, the mentality and lifestyle of the teenagers in African societies have been grossly affected by exposure to western films to some extent that rather than promoting African cultures, they have become hardened acolytes and promoters of western culture (p. 7).

Akande [36] blames globalization for the extinction of 22,000 indigenous cultures in the last decade and projects that approximately 90 percent of the world's languages will disappear in the next century as a result of globalization. One can go on and on and on in documenting all the negative effects of globalization on Nigerian cultures as documented by opponents of globalization. However a balanced and unprejudiced presentation will be required as the study also acknowledge the positive impacts of globalization on Africa, even though, the negative overshadow the positive aspect.

\section{The Way Forward}

Going by the empirical evidence from the literature, it is apparent that the values of brotherhood, social cohesion and social order which characterized traditional African communalism are affected owing to Western civilization, modernity, urbanization and above all globalization. In other words, the traditional African value system and the sense of cultural identity have given way to multi-ethnic and multicultural interactions. 
No doubt, a part of this study shows that globalization is yet another form of imperialist subjugation, but the need for an integration of African value system stems from the fact that globalization is a reality and has come to stay. It is an incontrovertible fact that colonialism existed on the continent of Africa. But now that it has ended what Africa need do is to synthesis the good legacies it left behind with the indigenous value system in order to have an integration of the two for the benefits of Africa.

Thus, the challenges posed by globalization to Africa are those that can easily be overcome. A proper integration of everything, African could be harnessed and be made to conform to the international standard. This attempt, it is believed, would make Africa not solely a dependent continent but also a player in the globalization process. Granted that Africa is poor in terms of the advancements in science and technology, but nothing much is wrong in borrowing technology and adapting it to suit the immediate needs of the African. Of course, there are variants benefits in scientific technological advancement but the caution Africans can take is to ensure that the technology that is borrowed or adopted does not erode the African value system.

The international media is also an avenue to exploit to boom Africa to the outside world. African drama and music which portrays the rich African cultural heritage with a fusion of contemporary modernity can be made to be seen by international audiences. Efforts are however been made in this area by the fast growing entertainment industry in Nigeria, particularly the evolution of Nollywood as the third largest movie producer in the world. If properly harnessed and sponsored by the government and private organizations, Nollywood could become an international revenue generation spinner. This is notably the drive behind the American Hollywood and the Indian Bollywood which makes them internationally recognized. The import of cultures these two carry along and their effects in the world today are undoubtedly innumerable.

Underpinning the concepts of digital media and globalization is the commitment to economic capitalism and liberal democracy. Africans should not take uncritical dispositions toward the economic, political and cultural ideology of the West in the disguise of globalization. African intellectuals, stakeholders and political leaders can revisit the basic principles underlying the traditional African communal economy and politics in an attempt to integrate these principles with what is obtainable in today's Africa. Since the Western market capitalism and liberal democracy have not helped Africa out of extreme poverty and underdevelopment, Africans could look inward to integrate their value systems which hinge on communalism with the under-current globalization.

\section{Conclusion and Recommendations}

The challenges digital media and globalization pose to Africa are nothing more than challenges for Africans to adopt development policies that are rooted in their cultural value systems. These are challenges that can make Africans develop their own model of contemporary African global realities. These are challenges that should make Africans take seriously the development of policies that would eradicate poverty and underdevelopment in the continent. These are challenges that should make Africans globalize their cultures in the face of increasing globalised Western cultures. These challenges when met with fierce determination would reduce the level of dependency of African countries on Western countries but would facilitate and strengthen interdependence among nations. This would make Africa a force to reckon with in the competitive global environment. The same way Africans adopt the western culture, the same way such western culture can be averted. Consequently, this study recommends as follows:

1. Africans should imbibe the positive tenets that come with technology and neglect the negative aspects.

2. Media proprietors should create programmes that are African oriented rather than copying the western perspective.

3. African researchers should develop interest in this area so as to expand the body of literature and knowledge.

\section{Acknowledgements}

We give God who gave the idea of writing this paper; we adore Him for inspiring and motivating us throughout the writing stage. May His name forever be glorified in Jesus name, amen.

\section{References}

[1] Aborishade, F. (2002). Effects of globalisation on social and labour practices in privatized enterprises in Nigeria. Research Report Submitted to Centre for Advanced Social Science, Port Harcourt, Nigeria.

[2] Abubakar, A. T. (2013). Selective believability: A perspective on African's interactions with global media. Retrieved from http://openaccess.city.ac.uk/3816/1/Selective\%20Belivabil.

[3] Abubakar, D. (2002). Globalisation, social sciences and Nigeria in the 21 st century. Nigeria Social Scientist, Vol. 4. No. 1.

[4] Acholonu, R. (2011). Mass media and cultural imperialism: The African experience. Retrieved from https://www.researchgate.net/publication/311245649_mass_m edia_cultural_imperialism_the_African_exprience.

[5] Akande, W. (2002). The drawback of cultural globalization. Yellow times.

[6] Akintayo, A. O. (2016). Influence of foreign programmes on the socio-cultural behaviour of undergraduates of Olabisi Onabanjo University, Ago-Iwoye, Ogun State, Nigeria. Novena Journal of Communication, 2, 107-118.

[7] Anaeto, S. Onabajo, O \& Osifeso, J. (2008). Models and theories of mass communication. Bowie, Maryland: African Renaissance Book Incorporated. 
[8] Asemah, E. S. (2018). Ideological influence of the Western press on the broadcast media content production in Nigeria: Oyo. Franco-ola Printers.

[9] Asemah, E. S. Nwammuo, A. N. \&Ukwam-Uwaoma, A. O. A (2017). Theories and model of communication (Rev. Ed) Jos: University Press.

[10] Ayayi, S. I. (2004). Globalization and equity in Sub-Saharan Africa: Themyth and the reality. University Press.

[11] Boli, J. \& George, M. T. (2003). World culture in the world policy. New York: America Sociology Review.

[12] Chigbo, R. (2007). Mass media in Nigeria: Perspectives on growth and development. Makurdi: Aboki Publishers.

[13] Croteau, D \& Hoynes, W. (2019). Media/society industries, images and audiences. London: SAGE Publications Ltd.

[14] Ekwuru G (2000). The pangs of an African culture in travail. Owerri:Totan publishers limited.

[15] Fafunwa, A. B. (2004). History of education in Nigeria. Revised edition, Ibadan: Samadex Nigeria Commercial Enterprises Ltd.

[16] Fischer, S. (2001). The challenges of globalization in Africa. The France-Africa

[17] Free Library, (2011). Media imperialism and its revisionist approach revisited: toward a synthesized analytical framework of television globalisation in China. Retrieved from http://www.thefreelibrary.com/media+imperalism.

[18] Izuogu, K. (2007). Globalisation and information technologies: problem and prospects in Nwosu \& Soola (Eds). Communication in Global, ICTs and Ecosystem PerspectivesInsights from Nigeria. Enugu: ACCE.

[19] Jenkins, H. (2006). Spreadable media. New York. NY: New York University Press

[20] Kelani, T. (2013). Death of language and culture. Tell Magazine, p. 17.

[21] King, A. (2000). Culture, globalization and the world-system. Minnesota: University of Minnesota Press.

[22] Kwame, Y. (2007). The impact of globalization on African culture. University of Southern Denmark.

[23] Leaning, M. (2017). FRSA. School of media and film, University of Winchester: UK.
[24] Mofoluwawo, E. O. (2010). Impact of cultural globalization on African moral values: the case of Nigeria. Social Studies Department Emmanuel Alayande College of Education, Oyo.

[25] Mohanty, P. K. (2005). Globalization, information technology and governance. Available at http://www.cgg.gov.in/workingpapers/workingpapers/globalan d goodgov/.pdf.

[26] Nicolaides, A. (2012). Globalization and Americanization: The hijacking of indigenous African culture. Global Advanced Research Journal of History, Political Science and International Relations, 1 (6).

[27] Nsibambi, A. (2001). The effects of globalization on the state in Africa: Harnessing the benefits and minimizing the costs. Paper presentedat UN general assembly, second committee; Panel discussion on globalization and the state.

[28] Obidi, S. S. (2005). Culture and education in Nigeria: A historical analysis, Ibadan: University.

[29] Ogoko A (2007). Globalization: ultra imperial ideation strategic for continued exploitation and underdevelopment of Africa. AMAMIHE J. Appl. Phil. p. 5.

[30] Oladiti, A. A. (2015). Swot analysis of cultural globalization on moral values in Nigerian society.

[31] Omoregbe, J. (2000). Ethics: A systematic and historical study. Lagos: Jaja Press Ltd.

[32] Oni, A. A. (2005). Globalization and its implication on Africa culture and development: Challenges for education, International Journal of African and African American Studies, 4 (2).

[33] Poe, M. T. (2011). A history of communications. New York, USA: Cambridge University Press.

[34] Proceeding of the 31st Annual National Conference of Social Studies Association of Nigeria, Oyo, Gbolagade Printing Press.

[35] Siapera, E. (2018). Understanding new media. London: SAGE Publications Ltd.

[36] Ugbam, C. O. Chukwu, B \&Ogbo, A. (2014). The effects of globalization on African culture: the Nigerian perspective. Journal of Business and Management. Vol. 16, (4) Ver. PP 6271. 